\title{
O świadomości historycznej uczniów w perspektywie edukacji polonistycznej
}

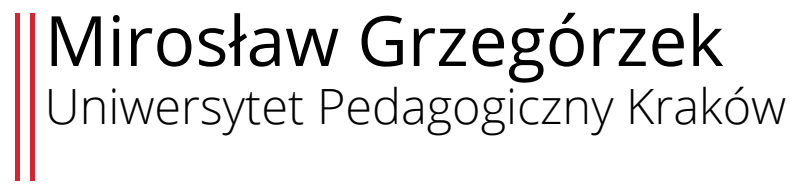

Jako dyplomowany nauczyciel języka polskiego oraz historii z wielkim zainteresowaniem sięgnąłem po książkę Doroty Karkut Miejsce i rola historii w edukacji polonistycznej. Badania i refleksje nad świadomościa historyczna uczniów (Wydawnictwo UR, Rzeszów 2017). Będąc przedstawicielem sporej grupy pedagogów o podobnej „podwójnej” specjalizacji humanistycznej, czuję się szczególnie predestynowany ${ }^{1}$ do zabrania głosu w dyskusji na temat wciąż niepoznanego, a zarazem esencjalnie humanistycznego „obszaru pomiędzy” dwiema dziedzinami refleksji humanistycznej w szkole, gdyż to właśnie na styku „godzin polskiego” i „nauki o przeszłości” badaczka z Uniwersytetu Rzeszowskiego sytuuje swoje eksploracje. W tak zarysowanej perspektywie już sam wybór tematyki badawczej jest - według mnie - dużym atutem pracy, którą potraktować można jako ważny krok postawiony na swoistej terra incognita międzyprzedmiotowego pogranicza.

Autorka określa główny cel swojej książki jako refleksję nad świadomością historyczną uczniów, która stanowi ważny element tożsamości kulturowej (s. 13). Wyniki długotrwałych i obfitych w zgromadzony materiał empiryczny badań, prowadzonych etapami w latach 2006-2014 w gimnazjach, szkołach ponadgimnazjalnych oraz $\mathrm{w}$ szkole wyższej², mają w zamierzeniu Karkut odpowiedzieć, w jaki sposób poznawanie literatury historycznej kształtuje zainteresowania przeszłością. W tym celu autorka przygląda się strategiom edukacyjnym polonistów, kształtującym świadomość historyczną uczniów, oraz próbuje wskazać korzyści dla nauczania literatury

\footnotetext{
${ }^{1}$ Autorka wielokrotnie w swojej książce podkreśla wyjątkowy status polonistów i historyków jako humanistów na tle innych profesji pedagogicznych (s. 12-13, 27, 59-61, 114, 156, 160, 181, 183, 195-197, 216).

${ }^{2}$ Brali w nich udział uczniowie, nauczyciele oraz studenci polonistyki i historii.
} 
i historii, płynące z korelacji obu przedmiotów. Opisuje także trudności i bariery we współpracy polonistów i historyków.

Problematyce badawczej poświęca autorka miejsce w rozdziale pierwszym. Wychodząc od zapisów („starej” już) podstawy programowej, definiuje cel edukacji polonistycznej, czyli zakorzenienie młodego człowieka w tradycji poprzez lekturę tekstów. Następnie dokonuje przeglądu dotychczasowych badań nad różnymi aspektami świadomości historycznej młodzieży i studentów z perspektywy wybranych dziedzin nauki (historia, socjologia, nauki o wychowaniu), by z kolei przedstawić cele podjętych badań teoretycznych i empirycznych, skupionych wokół problemu dotyczącego tego, w jaki sposób kształcenie polonistyczne może się włączać w rozwijanie świadomości historycznej. Badaczka poszukuje odpowiedzi na proste z pozoru pytania: co zaciekawia młodzież w historii, jak literatura historyczna wpływa na młodych (o ile ją czytają...), jaką rolę w kształceniu świadomości historycznej odgrywają podręczniki i działania nauczycieli, na czym polega integracja i korelacja między językiem polskim i historią. Opracowany materiał autorka stara się konsekwentnie konfrontować z opiniami ekspertów, zawartymi w pracach poświęconych szeroko pojętej edukacji humanistycznej.

Podjęcie tej a nie innej tematyki badawczej uzasadnia autorka kryzysem tożsamości, związanym z procesami globalizacji, konsumpcjonizmem, liberalizacją zachowań społecznych, kultem indywidualności, bezrefleksyjnym prezentyzmem i utylitarnością zdobywanej wiedzy. Młodzi, jak wynika z obserwacji nauczycieli i badaczy, żyją tu i teraz. Horyzont czasowy skrócony został do najbliższej przeszłości, którą przeżywa się zmysłowo, intensywnie i bezpośrednio. Kryzys myślenia historycznego obserwowany wśród młodzieży jest faktem. Historia, która - jak pisze przytaczany przez autorkę Marcin Kula - może być argumentem, punktem odniesienia, odwołaniem do korzeni, alfabetem, lepiszczem grupy, miejscem schronienia, rzeczą ciekawą i zabawną (s. 7), w pojęciu uczniów jest przede wszystkim katalogiem dat, postaci i zdarzeń niepowiązanych związkami przyczynowo-skutkowymi. I właśnie te, nienapawające optymizmem konstatacje, dały asumpt do wielowymiarowych i interdyscyplinarnych badań nad świadomością historyczną.

W rozdziale otwierającym książkę rzeszowska dydaktyk dokonuje także uporządkowania pojęć kluczowych dla dalszych ustaleń i osadza świadomość historyczną w kontekście takich zagadnień, jak historia, tożsamość (indywidualna, zbiorowa, kulturowa), doświadczenie, proces, narracja, etyka, podmiotowość, interpretacja, znak, pamięć zbiorowa, tradycja, kanon, lektura. Punktem odniesienia dla badaczki podczas tworzenia siatki pojęć są nie tylko ustalenia filozofów, psychologów, socjologów, pedagogów, historyków, ale przede wszystkim dydaktyków języka polskiego - Henryka Kurczaba, Wiesławy Wantuch (integracja, korelacja), Elżbiety Mikoś, Barbary Myrdzik, Anny Włodarczyk (interpretacja hermeneutyczna, etyka interpretacji). $\mathrm{W}$ dalszych partiach książki powołuje się również na 
tezy takich badaczy jak: Zenon Uryga, Marta Rusek (interdyscyplinarny, wielowymiarowy charakter godzin polskiego), Anna Janus-Sitarz (etyczne uwarunkowania lektury, szkolne praktyki czytania), Maria Jędrychowska, Bożena Chrząstowska (antropocentryzm, aksjologiczne konteksty edukacji), Zofia Agnieszka Kłakówna (konteksty kształcenia humanistycznego), Iwona Morawska, Barbara Kryda (dialogiczność literatury, tradycja), Stanisław Bortnowski (recepcja Sienkiewicza).

Z dokonanej przez Karkut analizy koncepcji teoretycznych wynika, że proces tworzenia tożsamości jest wynikiem obcowania z tradycją kulturową poprzez interpretowanie znaków, dzieł, tekstów przynależnych do dziedzictwa przeszłości. Tym samym istnieje ścisły związek między tożsamością a przeszłością. Świadomość historyczna, której szczególny element stanowi tradycja, jest strukturą mentalną i składnikiem kompetencji kulturowej, natomiast utrwalone $\mathrm{w}$ literaturze i historii uniwersalne wartości tworzą pamięć zbiorową, umożliwiającą wzajemną komunikację. Do porozumiewania się w sprawie własnej tożsamości służy kanon lekturowy (i historyczny, o czym pisze Andrzej Szpociński), kształtujący sposób myślenia o przeszłości i przyszłości, wzmacniający trwanie wspólnoty i konstytuujący ją.

Jak zauważa rzeszowska badaczka, w perspektywie edukacyjnej ważne jest analizowanie dzieł pochodzących z różnych epok (i traktujących o różnych epokach) - a szczególnie pokazywanie towarzyszących im kontekstów oraz związków i zależności interdyscyplinarnych. Z takiego humanistycznego podejścia do współczesnej polonistyki płyną korzyści zarówno dla kształcenia literackiego, jak i uczenia historii, choć w działaniach integrujących nauczycieli wskazana jest czujność i rozwaga. Nowocześnie rozumiane „godziny polskiego" służyć bowiem winny etycznym, egzystencjalnym i antropologicznym aspektom kształcenia, przy uwzględnieniu podmiotowości i antropocentryzmu jako fundamentalnych zasad polonistyki.

Rozdział drugi swojej pracy Karkut poświęca rozpoznaniu związków między literaturą i historią, a rozpoczyna go od zdefiniowania wyznaczników pisarstwa historycznego. Stwierdza, iż literatura jako nośnik pamięci konstruuje pamięć zbiorową (wiedzę, przekonania, stereotypy, postawy), a historia utrwalona w tekście literackim angażuje czytelnika, ukazując swą wielowymiarowość i wyjątkowy charakter, stając się źródłem motywów, tematów i problemów. Autorka zastanawia się, jak literatura piękna buduje wizerunek historii i broni tezy, że powieść historyczna umożliwia odwołanie się do emocji, wrażeń i przeżyć czytelnika, wpływając na atrakcyjność literackiego ujęcia historii. W erze nieczytania jest to niezwykle istotne. Nauczyciel musi jednak przy okazji uporać się z poważnym metodycznym wyzwaniem wiążącym się z tym, iż powieść historyczna jako gatunek zakłada czytelników posiadających minimum wiedzy i świadomości historycznej (s. 38-43).

Karkut podczas swoich analiz odwołuje się najczęściej do powieści historycznych Henryka Sienkiewicza (Krzyżacy, Quo vadis, Trylogia) 
oraz prozy dokumentarnej Aleksandra Kamińskiego i Arkadego Fiedlera. Szkoda, iż brak w tym zestawieniu innych ważnych tytułów, które pojawiają się na lekcjach języka polskiego, np. Rozmów z katem Kazimierza Moczarskiego czy $W$ stronę ciemności Gitty Sereny. Byłoby to uzasadnione tym bardziej, iż w prozie niefikcjonalnej XX wieku mamy do czynienia $\mathrm{z}$ „tekstualnością historii” i „historycznością literatury”, przenikaniem się obu typów dyskursów, zacieraniem granic między literaturą i historią. A przecież, jak twierdzi badaczka, świadomość wzajemnych związków literatury i historii może być podstawą efektywnej współpracy między szkolnymi polonistami a historykami.

W rozdziale trzecim Karkut dokonuje przeglądu koncepcji edukacji historycznej w perspektywie integracji języka polskiego i historii. Na wstępie stawia kontrowersyjną (lub co najmniej wymagającą uściślenia) tezę, że obecnie mamy do czynienia ze „zwrotem ku przeszłości”, „eksplozją pamię$\mathrm{ci}^{\prime \prime}$. Tym ważniejsze staje się więc nie tylko zdobywanie wiedzy, lecz rozwijanie myślenia historycznego przez kształtowanie przekonań i wartości odnoszących się do przeszłości. W końcu „istotą edukacji historycznej jest poznawanie przeszłości na podstawie historii stworzonych przez innych oraz własnego doświadczenia dziejów i tworzenie swojej wizji przeszłości" (s. 52). Służyć temu może na przykład refleksja nad kreacją postaci historycznych, które dzięki literaturze otrzymują wielowymiarowy, „realny” kształt.

Rzeszowska dydaktyk próbuje również znaleźć wspólny mianownik dla międzyprzedmiotowych związków, porównując zapisy wymagań zawarte w "starych” podstawach programowych do historii i języka polskiego. Tym wspólnym mianownikiem byłoby kształcenie umiejętności interpretacyjnych, związanych z krytyczną lekturą tekstów, zawierających elementy fikcji i prawdy historycznej, do czego przydatny okazać się może „podwójny tryb lektury" (historyczny i prezentystyczny), oraz postawa nauczyciela-przewodnika, który staje się - jak pisze Marta Rusek - „wyzwolicielem uczniowskiego integrującego doświadczenia" (s. 60).

Dorotę Karkut interesują również konteksty historyczne wpisane w literaturę zalecaną do czytania na poszczególnych etapach edukacji. Stwierdza ona, że o proponowanym wyborze decyduje to, czy lektury ukierunkowane są na wychowanie ku wartościom, wśród których szczególną rolę odgrywa patriotyzm ${ }^{4}$.

Rozdział czwarty Karkut poświęca koncepcji kształcenia historycznego, wpisanego w strukturę programów i podręczników do języka polskiego i historii. Swoje rozważania rozpoczyna od analizy zapisów podstawy programowej, by przejść następnie do omówienia wybranych kontekstów historycznych w programie To lubię! dla szkoły ponadgimnazjalnej. Dalsza część

\footnotetext{
${ }^{3}$ Można mieć wątpliwości, czy ta diagnoza dotyczy młodych, zwłaszcza w świetle przytaczanych przez autorkę wyników badań H. Świdy-Ziemby.

${ }^{4}$ D. Karkut postrzega również edukację patriotyczną jako przestrzeń integracji międzyprzedmiotowej (s. 201-203).
} 
rozdziału poświęcona jest tropieniu kontekstów historycznych w wybranych podręcznikach (oraz programach) z III i IV etapu edukacji. W przywoływanych przykładach zwraca uwagę na sposoby aktualizowania przeszłości, funkcje materiałów ikonograficznych oraz znaczenie opracowania edytorskiego ${ }^{5}$ i na to, jak te elementy sprzyjają wprowadzaniu uczniów w tradycję.

Badaczka przygląda się również problematyce aksjologicznej w wybranych podręcznikach. Dostrzega, że ich twórcy kierują uczniów w stronę wartości uniwersalnych: miłości, cierpienia, tolerancji, wolności, ale również ukazują mity, symbole i postaci najpopularniejsze w różnych okresach kultury (ze szczególnym uwzględnieniem dzieł Sienkiewicza, które odegrały niebagatelną rolę $\mathrm{w}$ tworzeniu i utrwalaniu narodowych mitów).

W recenzowanej pracy warto zwrócić uwagę na interesujące wnioski z badania dotyczącego oceny podręczników do języka polskiego jako nośników wiedzy historycznej. Okazało się, że korzystający z nich negatywnie oceniają skrótowość, fragmentaryczność bądź niedostatek pierwiastka historycznego. Obecność kontekstów historycznych w podręcznikach do polskiego jest ich zdaniem ważna dlatego, iż stanowią one przeważnie jedyne źródło wiedzy historycznej, do którego inną drogą żaden uczeń by nie trafił. Z perspektywy polonistyki szkolnej ważne są także ustalenia Karkut dotyczące tych zagadnień poruszanych w edukacji historycznej, które uczniowie lubią; a są to wojna i życie codzienne w dawnych wiekach. Istotną rolę motywacyjną pełnią również ciekawostki, sensacje, legendy i anegdoty z życia sławnych postaci.

Mocną stroną recenzowanej monografii są rozdziały prezentujące wyniki badań empirycznych. Badaczka przedstawia na przykład zainteresowania historyczne gimnazjalistów oraz młodzieży szkół średnich, starając się odpowiedzieć na kilka ważnych pytań: Jaką wiedzą historyczną dysponuje uczeń? Jaki jest stosunek młodych ludzi do historii? Jakie są ich preferencje w ocenie okresów historycznych ${ }^{6}$, dziedzin, wydarzeń i postaci? Analiza wypowiedzi uczniowskich przynosi wiele informacji, które zmuszają do refleksji. Młodzi mówią „nie” historii, bo jest nudna, nieprzydatna do niczego i wymaga „wkuwania na pamięć”. Większość młodzieży traktuje historię w sposób instrumentalny, ucząc się dla ocen. Nie dziwi zatem, że 1/5-1/4 badanych uczniów nie ma swojego ulubionego okresu historii (można założyć, że taki procent respondentów nie lubi historii w ogóle, choć jednocześnie, według badań autorki, historia zajmuje czwarte miejsce wśród ulubionych przedmiotów w gimnazjum, natomiast drugie w szkole ponadgimnazjalnej (s. 116)). Badaczka pokazuje również, jak zainteresowania konkretnymi treściami historycznymi uwarunkowane są płcią (chłopcy - wojna, wojskowość; dziewczyny - życie codzienne, kultura, obyczaje). Zwraca

\footnotetext{
${ }^{5}$ Choć trudno mi się zgodzić z twierdzeniem, że graficzne zestawienia informacji zapobiegają mechanicznemu przyswajaniu wiadomości (s. 89).

6 W sformułowaniu „okresy historyczne” widać dobrze założoną przez autorkę perspektywę polonistyczną podjętych badań. Z frazeologicznego punktu widzenia historyk użyje sformułowania „epoka historyczna”, literaturoznawca „okres literacki”.
} 
także uwagę, iż podstawowym źródłem wiedzy historycznej są dla młodych lekcje historii, a w drugiej kolejności książki i środki masowego przekazu.

Część swoich rozważań autorka poświęca wpływowi książek na zainteresowania historyczne młodzieży szkolnej. Badani przez nią gimnazjaliści najczęściej wskazywali, że tę rolę pełnią podręczniki, encyklopedie i powieści historyczne z kanonu. Niezbyt optymistycznie wypadło jednak przyporządkowanie książek historycznych do konkretnych epok historycznych. Badania autorki pokazują również, że jeśli gimnazjaliści czytają książki historyczne, to dlatego, że interesują ich wybitne postacie, wartka, sensacyjna akcja, anegdota. Licealiści wskazują również wartką akcję, sensację i postacie historyczne jako czynniki przyciągające do lektury książek historycznych.

Warto w recenzowanej publikacji przyjrzeć się także tym fragmentom, w których autorka przedstawia wyniki badań dotyczących uczniowskiego odbioru literatury czytanej w ramach tzw. przymusu lekturowego. Okazało się, że połowa ankietowanych uczniów deklaruje niechęć do czytania książek historycznych. Uczniów nie ciekawi przeszłość i niewielu badanych poleciłoby innym teksty Sienkiewicza, Kamińskiego, Fiedlera (dokładne dane procentowe są na s. 137). Jedną z przyczyn tego stanu rzeczy są bariery recepcyjne. Autorka analizuje również, jak uczniowie postrzegają i rozumieją twórczość Sienkiewicza. Dość powiedzieć, że połowa badanych nie potrafiła (lub nie chciała) dokonać analizy obrazów przeszłości ukazanych w Krzyżakach, Potopie lub Quo vadis. Wypowiedzi respondentów wskazują na trudności w odbiorze tych tekstów, o czym decydują język i tematyka historyczna, sposób charakteryzowania postaci, odległość od doświadczenia uczniowskiego (nuda), grubość książki, rozbudowane opisy. Sienkiewicz zdaje się być całkowicie odrzucony (tylko na 16\% badanych ta twórczość w jakiś sposób oddziałuje). Co ciekawe, badanie pokazuje przy okazji, że aż $60 \%$ respondentów uznaje opowieści Sienkiewicza za prawdę historyczną, a przecież - jak pisze Zofia Budrewicz - beletrystyka nie może być źródłem wiedzy historycznej, jest jedynie interpretacją powstałą dla określonych celów artystyczno-ideologicznych (s. 147). Jak zatem sprawić, żeby uczeń sięgnął na przykład po Quo vadis? Z punktu widzenia refleksyjnego praktyka to jest dzisiaj podstawowa kwestia, inaczej nie sposób oczekiwać, by uczeń był w stanie zająć jakiekolwiek stanowisko wobec noblisty i jego dzieł.

$\mathrm{Na}$ kolejnych stronach rzeszowska dydaktyk dokonuje jakościowego przeglądu wypowiedzi uczniów (s. 148-156) i studentów (s. 156-159) na temat roli Sienkiewicza jako metonimii polskości. Okazało się, że jedni postrzegają go jako ciągle żywy fenomen, niezbędne ogniwo w zdobywaniu wiedzy o nas samych jako Polakach, zaś inni, w duchu futurystycznym, chętnie wywieźliby noblistę na śmietnik historii wraz z „nieświeżymi mumiami Mickiewiczów i Słowackich" (s. 148, 159-162).

Karkut interesuje się także uczniowskim odbiorem literackich obrazów II wojny światowej w literaturze dokumentarnej (Kamienie na szaniec, Dywizjon 303), która cieszy się większym zainteresowaniem niż powieści 
historyczne Sienkiewicza, o czym decyduje swoisty autentyzm historyczny (a w mej opinii również, niewzięta przez badaczkę pod uwagę, skromniejsza objętość woluminów...). Warto zauważyć, że zaprezentowane przez nią badania pokazują, jak ważna w szkole może być idea dialogowego modelu lektury (jako rozmowy z przeszłością) i tradycji (stapianie horyzontu przeszłości i współczesności; tradycja jako konstytuanta współczesności). W tym kontekście lekcyjna rozmowa na temat patriotyzmu nie byłaby dyskusją na temat gotowości poniesienia ofiary z życia, co raczej krytyczną refleksją nad istotą tej wartości, którą w ramach własnych poczynań lekcyjnych starałem się zainicjować na przykład w następującym temacie rozprawki: „3 maja 1943 r. Zośka wydał harcerski rozkaz, który poświęcił pamięci Rudego i Alka. Ostatnie zdanie brzmi tak: >>Janku i Alku, czuwamy i potrafimy pójść zawsze waszymi śladami $<<$. Czy dziś potrafiłabym/ potrafiłbym pójść śladami któregoś z bohaterów Kamieni...?" Według mnie, to właśnie stawianie podobnych pytań jest kwintesencją rozmów o książkach (nie tylko zresztą historycznych).

$\mathrm{W}$ ostatnim rozdziale recenzowanej monografii zaprezentowane zostały m.in. wyniki badania dotyczącego znajomości postaci historycznych jako wyznacznika świadomości historycznej oraz ważnego kontekstu potrzebnego do analizy dzieł literackich. Uczniowie szkół ponadgimnazjalnych wymienili ogółem 113 postaci historycznych - przywódców, polityków, odkrywców. Rzadziej wskazywano przedstawicieli świata nauki, sztuki, kultury. Autorka podkreśla, iż analiza zgromadzonego materiału empirycznego pozwala jedynie na „ostrożne” uogólnienia (s. 194). Po pierwsze młodzi dysponują czysto szkolną, ogólną wizją historii, opinie o postaciach są płytkie i stereotypowe. Młodzież zna, i to w mocno ograniczonym zakresie, przede wszystkim nazwiska trwale obecne w szkolnej edukacji. A przecież jeśli w tej galerii postaci poszukuje się autorytetu, to nie wystarczy jedynie poznanie ich życiorysów; niezbędne jest przejście przez fazę zainteresowania, podziwu, dostrzeżenia wartości, ich akceptację, aktualizację i realizację (o ile mowa o pozytywnej mocy autorytetu).

Karkut w swojej pracy omawia również charakter i formy współpracy polonistów i historyków w szkole, prezentując pozytywny przykład takiej współpracy w ramach edukacji regionalnej w Kolbuszowej. Dydaktyków akademickich zainteresują być może wyniki badań przeprowadzonych wśród studentów polonistyki i historii poświęconych ich przygotowaniu do integracji treści obu przedmiotów.

Monografia Karkut odsłoniła pejzaż aksjologiczny, w którym żyją młodzi ludzie: nie interesują się historią, nie czytają, a więc nie mają bogatej wiedzy historycznej, a jeśli już się na nią powołują, to jest ona chaotyczna i fragmentaryczna (s. 228). Niski jest też ich poziom świadomości historycznej. Młodzież nie dostrzega również potrzeby odwoływania się do kontekstu historycznego. Tymczasem coraz bardziej realne jest niebezpieczeństwo życia w świecie bez historii, który może stać się całkowicie 
odhumanizowany. „Tym bardziej istotne staje się rozwijanie u uczniów zmysłu historycznego i kształtowanie upodobań literackich, które pozwolą zrozumieć, przeżyć i docenić dzieła z przyszłości" (s. 230). Książka Karkut może się temu przysłużyć, będąc ważną lekturą zarówno dla polonistów, jak i historyków.

\section{O Autorze:}

Mirosław Grzegórzek - doktorant w Katedrze Dydaktyki Literatury i Języka Polskiego UP im. KEN w Krakowie. Nauczyciel dyplomowany języka polskiego (absolwent WSP/AP im. KEN) oraz historii i wiedzy o społeczeństwie (absolwent UPJPII w Krakowie) w szkole podstawowej. Zainteresowania: genologia szkolnych gatunków wypowiedzi, stylistyka praktyczna, metodyka ćwiczeń w mówieniu i pisaniu, narracyjne i antropologiczne konteksty odbioru literatury w szkole. 